\title{
Chapter 19 \\ Threatening the Harvest: \\ The Threat from Three Invasive \\ Insects in Late Season Vineyards
}

\author{
Douglas G. Pfeiffer, Tracy C. Leskey, and Hannah J. Burrack
}

\subsection{Introduction}

\subsubsection{Scope}

An integral goal of integrated pest management programs is to reduce the pesticide load in the cropping system. Reducing pesticide applications will generally lower pressure to develop pesticide resistance, enhance the presence of beneficial arthropods, and reduce unintended effects on beneficial arthropods, environment, farm workers, and consumers. It is generally desirable to eliminate late season applications, because such applications would lead to the highest residues at harvest. The fact that growers must observe label pre-harvest intervals (PHIs) is often a complicating factor in vineyard management. In recent years, three invasive species from Asia have become pests in North American vineyards. The purpose of this chapter is to discuss their biology, the relationship of their injury to grape harvest, and possible management approaches.

D.G. Pfeiffer $(\bowtie)$

Department of Entomology, Virginia Tech., 205C Price Hall, Blacksburg,

VA 24061-0319, USA

e-mail: dgpfeiff@vt.edu

T.C. Leskey

USDA-ARS, Appalachian Fruit Research Station, 2217 Wiltshire, Road,

Kearneysville, WV 25430, USA

e-mail: tracy.leskey@ars.usda.gov

H.J. Burrack

Department of Entomology, North Carolina State University, Research Annex West,

Ligon Road, Box 7630, Raleigh, NC 27695-7630, USA

e-mail: hannah_burrack@ncsu.edu 


\subsection{Brown Marmorated Stink Bug}

\subsubsection{Introduction}

The brown marmorated stink bug (BMSB), Halyomorpha halys (Stål), is sometimes called yellow-brown stink bug or east Asian stink bug (Hoebeke and Carter 2003; Hamilton et al. 2008). The native range of BMSB is northeastern Asia (China, Korea, Taiwan, and Japan). In the United States, this species was first collected in Allentown, Pennsylvania, in 1996 (Hoebeke 2002; Hoebeke and Carter 2003). In 1999, it was first detected in New Jersey in a blacklight trap, though BMSB was not officially identified until 2001 based on two specimens collected near Allentown, Pennsylvania. Officially, this insect was identified as present in New Jersey in 2002, Maryland in 2003, and in West Virginia in 2004. An isolated population was found in a recreational vehicle in Maine, recently arrived from Maryland, where there was a known BMSB population (Maine Department of Agriculture 2006). Hamilton et al. (2008) reported BMSB as feeding on peach, pear, raspberry, string beans, asparagus, as well as many ornamentals. At the time, it was not clear whether this species would become a widespread pest in the US (Wermelinger et al. 2008). While widespread across Virginia since its first detection there in 2004 (Day et al. 2011), it was first reported as a nuisance in buildings in 2008-2009, and in 2010 it caused significant damage in orchards and vineyards throughout the mid-Atlantic region. It was detected in 2005 in California, in items stored by a resident that had recently arrived from Pennsylvania (CDFA 2005). It was intercepted in Florida, with no indication of establishment (Halbert 2009; Gyeltshen et al. 2010), and in 2009 it was collected in Tennessee (Jones and Lambdin 2009). There have been isolated reports from Massachusetts and Ohio as well (Welty et al. 2008). Officially, the United States Department of Agriculture-Animal and Plant Health Inspection Service (USDA-APHIS) has reported that BMSB has been detected in 35 states and the District of Columbia as of November 2010. Detection does not necessarily indicate establishment but it rather indicates a potential risk of establishment. The brown marmorated stink bug has also been introduced into Switzerland (Wermelinger et al. 2008). The taxonomy of this species has been unclear, but there is apparently only one species of Halyomorpha in eastern Asia (H. halys), and all other names from this region (e.g., H. mista (Uhler)) are considered synonyms (Rider 2005).

\subsubsection{Appearance}

The adult (Fig. 19.1) has a typical pentatomid shape, flattened, broad and shieldshaped. Females are slightly larger than males (length $15.6 \mathrm{~mm}, 13.6 \mathrm{~mm}$, respectively, and width (humeral area) $9.0 \mathrm{~mm}, 7.6 \mathrm{~mm}$, respectively). Adults are brown, flecked with white (hence the common name marmorated, or marbled). The edge of the abdomen has alternating dark and white spots, and there are white bands on the 


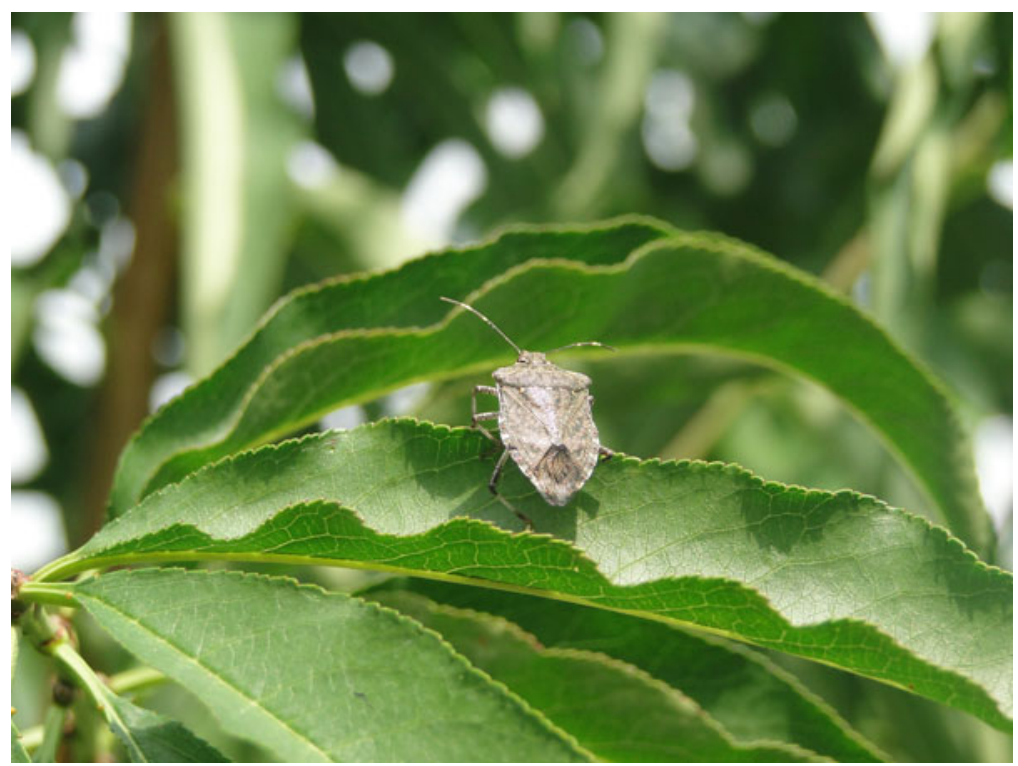

Fig. 19.1 Adult brown marmorated stink bug

antennae and tibiae. The most likely insects to be confused with BMSB are stink bugs in the genus Brochymena (Hoebeke 2002). However, Brochymena spp. have a dentate or crenulate margin of the pronotum, which is smooth in BMSB. Sexes can be differentiated by the forked appearance of the last sternite of the abdomen (Niva and Takeda 2002).

Eggs are barrel-shaped, laid in groups of about 28 (Nielsen et al. 2008a), and nymphs have markings of red and white on the abdomen (Fig. 19.2). The following characters may be used to identify the instars (Hoebeke and Carter 2003): first instar - eyes not projecting; second instar - eyes spherically projecting; third instar - development of white bands on tibiae; fourth instar - anterior wing pads only; fifth instar - posterior wing pads in addition to the anterior ones (Fig. 19.3).

\subsubsection{Biology}

The brown marmorated stink bug has a wide host range, including many fruit, vegetable and ornamental plants, including apple, pear, grape, kidney bean, pea, and cucumber (Panizzi et al. 2000). The host list is probably about 300 species (Nielsen and Hamilton 2009a). In the review of Pentatomidae by Panizzi et al. (2000), little was known of the life history of this species, despite it being an important pest of commercial crops in Japan. In Japan, BMSB uses Prunus trees as reproductive hosts. Overwintered adults appear on trees in early June, and females already have eggs 


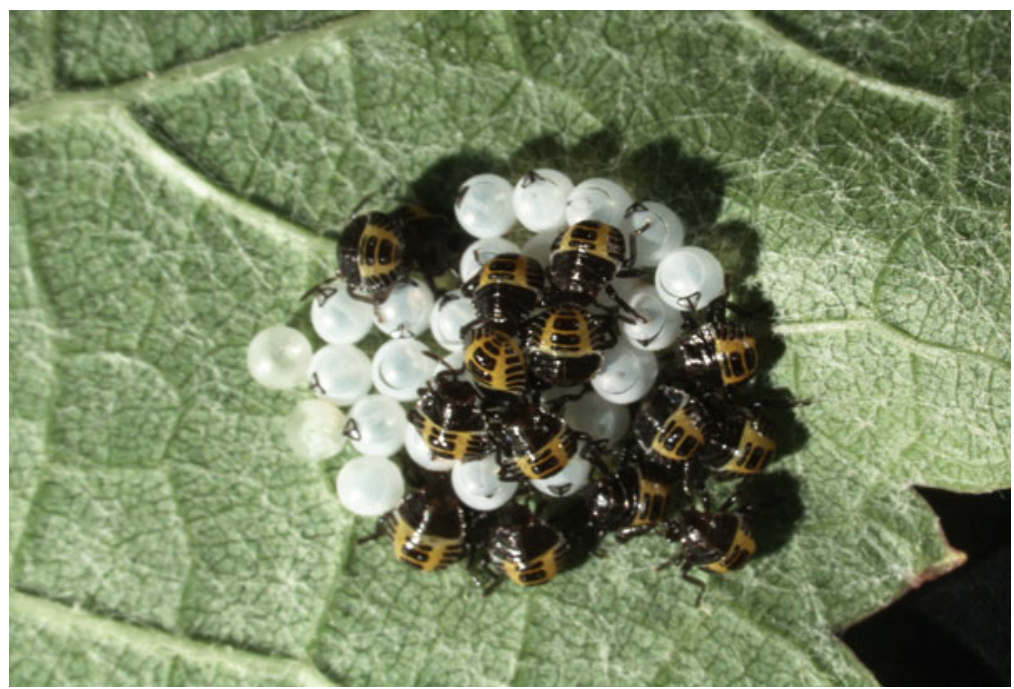

Fig. 19.2 Egg mass and first-instar brown marmorated stink bug nymphs (Photo by Eric Day)

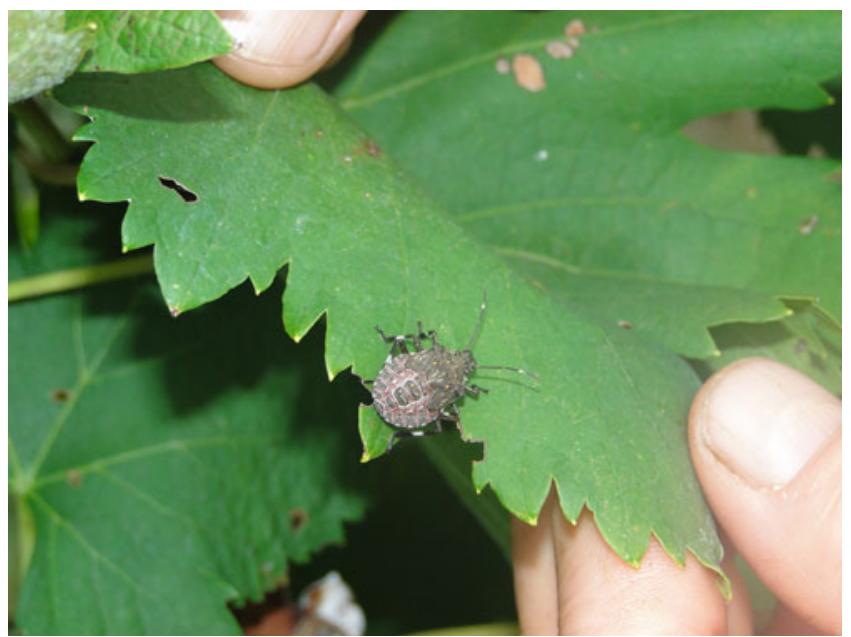

Fig. 19.3 Fifth instar nymph of brown marmorated stink bug

ready for oviposition. Trees have developing nymphs all season (Funayama 2007). After the final molt to the adult stage, a further 14 days are required for sexual maturation (Kawada and Kitamura 1983). If mated once, a female can produce eggs for about half her life span, but females commonly mate multiple times, even up to five times a day, with duration of copulations averaging $10 \mathrm{~min}$. There is generally one generation in most of Asia and apparently in Pennsylvania (Hoebeke 2002; Funayama 
2007) and in New Jersey (Nielsen and Hamilton 2009a). Hoebeke and Carter (2003) cite Hoffmann (1931) who reported up to six generations in the southern part of its range in China. The potential for multiple generations of BMSB in more southerly locations in North America is supported by a 2010 field cage study conducted in the eastern panhandle of West Virginia. The study showed that two distinct generations completed their development within approximately 50 days from egg to adult under field conditions (T.C. Leskey et al., unpubl. data). A modeling study in New Jersey estimated that 537.63 growing degree-days (DD) are needed for total development (egg to adult eclosion). An additional 147.65 DD are needed for the 2-week preovipositional period of the female (Nielsen et al. 2008a). Brown marmorated stink bug eggs have been found hatching in a commercial vineyard in Orange County, Virginia, in the first week of June (D. G. Pfeiffer, unpubl. data).

Kiritani $(2006,2007)$ pointed to the potential impact of climate change on BMSB populations with winter mortality predicted to decrease by $15 \%$ with a rise in temperature of $1{ }^{\circ} \mathrm{C}$ and the potential for increase in the number of generations per year for BMSB and other bug species that attack rice and fruits.

Stock cultures have been maintained on a diet of shelled sunflower seeds for nymphs, and peanuts for adults, with water containing $0.5 \%$ ascorbic acid and $0.25 \%$ L-cysteine. Carrot has also been used to augment standard soybean-peanut diets for BMSB cultures with reportedly increased colony viability (Funayama 2006).

In New Jersey, Nielsen and Hamilton (2009a) reported that BMSB eggs were first seen on the Empress tree, Paulownia tomentosa (Thunberg) Steudel. Ash (Fraxinus americana L.) was an important mid- and late season host for adults. Nymphal abundance shifted among hosts during the season. Paulownia tomentosa supported high populations early in the season, while Viburnum opulus L. var. americanum Aiton was a preferred mid-season host. In the late season, highest nymphal densities were found on Viburnum prunifolium L. and Rosa rugosa Thunberg. Given the univoltine cycle established in this study, the shifting nymphal population reflects adults changing their preferred oviposition sites. Abundance of nymphs was strongly associated with the presence of maturing fruit or pods.

The defensive scent glands of BMSB have been reported to be located on the dorsal surface of the abdomen and ventral surface of the thorax (Hamilton et al. 2008), but their chemical ecology has been little studied. However, there is a pattern in related bugs of nymphs having dorsal abdominal scent glands, which decline in importance at the adult molt, when the metathoracic scent glands become functional (Aldrich 1988). The defensive odor of BMSB was reported to be trans-2-decenal and trans-2-octenal in a web site (EOL 2011), but the support for this assertion is a study completed using unidentified stink bugs before BMSB could have been in the area (Henderson et al. 2006).

In addition to their defensive odors, pentatomids use male-produced aggregation pheromones. An aggregation pheromone has not been specifically identified for BMSB. However, in Asia, it has been attracted to methyl (E,E,Z)-2,4,6-decatrienoate, the pheromone of another East Asian pentatomid, Plautia stali Scott (Aldrich et al. 2007). This compound attracts female and male adults, as well as nymphs (Khrimian et al. 2008). Using this material, BMSB has been detected in traps in Maryland, 
and from 2004 to 2008 it became more commonly trapped than the green stink bug, Acrosternum hilare (Say), which responds to the same chemical (Aldrich et al. 2009). Diapausing BMSB likely respond to short-range chemical stimuli that result in overwintering aggregations (Toyama et al. 2006), although no specific stimuli associated with this behavioral response have been identified.

\subsubsection{Injury}

\subsubsection{Feeding Injury}

Little work has been done on feeding effects on grapevines. Stink bugs have traditionally not been considered to be important grape pests. This may change with the high populations of BMSB seen recently at harvest in the mid-Atlantic region of the United States. There has been a grower account of BMSB feeding on the rachis, causing abscission of clusters, with loss of several ha of grapes in 2010 (S. Dorn, pers. comm.). Collapsed berries among table grape cultivars were detected on farms in the mid-Atlantic region, and there is a concern that feeding punctures may increase incidence of fruit rots. More work has been done on tree fruit crops than on grapevines. During mid- and late season growth stages, apples and peaches are susceptible (Nielsen and Hamilton 2009b). During final pit hardening and final growth, feeding impacts are most visible. Early feeding (petal fall in apple, shuck split in peach) results in premature abscission of fruit. In 2010, severe BMSB feeding injury was detected in commercial peach and apple orchards in the mid-Atlantic region. Fruit injury ranged from $15-85 \%$ and $25-80 \%$ among commercial peach and apple orchards, respectively (T. C. Leskey, unpubl. data). One grape grower reported BMSB feeding on the rachis of grape clusters resulted in loss of berries equal to the production of 1.2-1.6 ha in 2010 (S. Dorn, pers. comm.). Not only would the resulting nymphs have easy access to the rachis, but at this time of the season, expanding berries and leaf canopies would impede spray coverage of this area.

\subsubsection{Impact of Presence for Wine Quality}

Another pressing concern regarding BMSB in vineyards is the result of bugs being collected along with clusters at harvest, and being transported in lugs or bins to the winery. If crushed with the berries, they can impart a noticeable odor or flavor, referred to as 'stink bug taint'. Although BMSB has been noted in Virginia vineyards for a few years, populations became much more severe in 2010, and the taint imparted to juice aroused the concern of vineyard/winery managers (Kelly 2010). A preliminary study showed that as few as 10 adult BMSB per lug can taint the wine (J. Fiola, pers. comm.). Further research is needed on the minimum number of bugs 
needed to impart a noticeable taint, and on the stability of this effect in the finished wine. This is currently an area of research in Maryland and Virginia.

\subsubsection{Role as Plant Disease Vector}

The brown marmorated stink bug is the vector of the phytoplasma that causes witches broom in P. tomentosa (Weintraub and Beanland 2006). Since this phytoplasma also attacks roses, and phytoplasma vectors sometimes carry more than one phytoplasma species, Jones and Lambdin (2009) speculated on potential economic impact of BMSB in North America. The relevance of this reasoning remains to be seen for vineyards.

\subsubsection{Role as a Nuisance Pest}

In its native range, BMSB congregates on buildings in autumn, entering them for the winter, and becoming a nuisance (Hoebeke 2002). This habit has created a public prominence in the eastern US as well (Day et al. 2011). Unprecedented numbers of BMSB invading buildings in 2010 elicited much public concern. During warm days in the fall, large numbers gather on the sides of buildings, especially on southand west-facing walls. They enter buildings through cracks at doors and windows, and may enter interior rooms either directly, or later from attics and other spaces. As populations develop in grape-producing regions, this may become a significant concern for winery and tasting room managers.

\subsubsection{Management}

\subsubsection{Chemical Control}

Effective control of BMSB using insecticides has been difficult. The most effective classes have been the pyrethroids and the neonicotinoids. Whereas it is possible to reduce populations immediately after a treatment, it is more difficult to prevent reinfestation. In a glass-vial bioassay, bifenthrin was found to be highly toxic (Nielsen et al. 2008b). Other pyrethroids tested, with similar toxicity, were beta-cyfluthrin, cyfluthrin, fenpropathrin, and lambda-cyhalothrin. Recovery was recorded with all the pyrethroids. Neonicotinoids (dinotefuran, acetamiprid, and thiamethoxam) were also very toxic. The organophosphate phosmet had $\mathrm{LD}_{50}$ values almost fourfold higher than other insecticide classes tested. Nymphs were more sensitive to insecticides than adults, and females were more sensitive than males, despite being larger.

A list of insecticides ranked with a 'lethality index' (ranking materials from 0 to 100) was presented by Leskey (2011). This index reflects both immediate mortality, 
as well as the effect of recovery from initial paralysis. There was considerable variation in the lethality index within pesticide classes, e.g., dimethoate (93.3) and malathion (92.5) at the upper end of the range, and phosmet (20.0) near the lower end. Bifenthrin (91.5) was at the upper end of the pyrethroid class, with esfenvalerate (43.3) much lower. Insecticides on this list that are registered in the US for grape, with the associated lethality index values, are: malathion (92.5), bifenthrin (91.5), endosulfan (90.4), dinotefuran (67.3), fenpropathrin (66.7), kaolin + thiamethoxam (66.7), thiamethoxam (56.3), clothianidin (55.6), beta-cyfluthrin (54.8), zeta-cypermethrin (52.1), cyfluthrin (49.0), imidacloprid (40.0), kaolin (23.1), diazinon (20.4), phosmet (20.0), acetamiprid (18.8), abamectin (16.3), indoxacarb (11.3), spirotetramat (9.8), carbaryl (9.2), and cyantraniliprole (1.7).

Given the late season infestation seen in vineyards, and the problem of harvesting bugs along with the fruit, the PHI becomes of great importance. The following materials may be recommended and are available for BMSB control (followed by Restricted Entry Interval and PHI): pyrethroids: fenpropathrin (24 h, 21 days), cyfluthrin (12 h, 3 days), neonicotinoids: acetamiprid (12 h, 7 days), clothianidin (12 h, 0 day), dinotefuran (12 h, 1 day), imidacloprid (12 h, 0 day), carbamates: methomyl ( 7 days, 14 days), chlorinated hydrocarbons: endosulfan ( 24 h, 7 days), botanicals: pyrethrin (PyGanic ${ }^{\circledR} 1.4 \%$ or $5 \%$ ) (12 h, 0 day), pyrethrin plus Canola oil (12 h, 0 day).

In a vineyard study, PyGanic ${ }^{\circledR}$ and clothianidin were both used successfully to eliminate BMSB from clusters by applying them with an airblast sprayer late in the day preceding harvest (Pfeiffer et al. 2010).

A disadvantage of the pyrethroid class is the extremely damaging effect on populations of beneficial arthropods. It is common to see induction of secondary pest outbreaks, including spider mites and mealybugs. The latter is of special interest to vineyard managers, since mealybugs are the vectors for grapevine leafroll virus. Mealybug outbreaks and subsequent infection by leafroll virus have been noted following pyrethroid application for grape berry moth, Paralobesia viteana (Clemens) (D. G. Pfeiffer, unpubl. data). Sometimes there are also negative impacts of neonicotinoids on beneficial species. If insecticides are needed, special attention should be paid to vineyard edges, where populations of BMSB are often higher.

\subsubsection{Biological Control}

A tachinid fly in the genus Bogosia was reported parasitizing BMSB in Japan. The female laid an egg on the pronotum of the bug. After entering the host, the larva consumed the reproductive system, and sterilized the host. The tachinid larva then left the host to pupate. Parasitism of nymphs has also been observed (Kawada and Kitamura 1992). Parasitization rates were reported between 6\% and 7\% (Kawada and Kitamura 1983) and $>10 \%$ for overwintering adults (Kawada and Kitamura 1992). In an 8-week survey in China, Koppel (2010) found BMSB eggs to be parasitized by Trissolcus halyomorphae Yang in four different host plants in Nanjing, Kunming, and Xi' an. Parasitization rates can reach $70 \%$, with annual mean 
parasitization of $50 \%$ (Yang et al. 2009). A picorna-like virus, named P. stali intestine virus (PSIV), was found infecting the brown-winged greenbug, $P$. stali Scott. It was also found infecting BMSB. Infected $P$. stali have an adult life span of about 13 days, compared to about a month in non-viruliferous adults (Nakashima et al. 1998).

\subsubsection{Mechanical Control}

Infestations in dwellings can be controlled by sealing and screening openings, to reduce numbers entering the dwelling. Light fixtures, exhaust fans and baseboards are sealed with caulk to keep those that have entered attics and basements from entering interior rooms (Day et al. 2011). Insecticides may be applied to the sides of the dwelling, but this should be done by a professional.

\subsection{Spotted Wing Drosophila}

\subsubsection{Introduction}

Native to eastern Asia, the spotted wing drosophila (SWD), Drosophila suzukii (Matsumura), is a pest of soft skinned fruit. It has recently been detected in and spread throughout North America. Markow and O'Grady (2006) recognize D. suzukii as a complex of the suzukii subgroup, within the melanogaster species group, with the following description of ranges: 'Drosophila mimetica ... is known from Malaysia, $D$. lucipennis ... is disjunctly distributed in eastern India and Taiwan, D. biarmipes ... is known from India and Sri Lanka to southeast Asia, and D. pulchrella ... is found from India, China, and southeast Asia to Japan.'

The spotted wing drosophila invaded Hawaii several years ago (Walsh et al. 2011). Since Hawaii is a US State, some considered this was therefore already a US pest, complicating later detection and management efforts. Upon its detection in Florida in late 2009, USDA-APHIS declared that it was not a regulated pest, so there would be no eradication program (Lehnert 2010). The spotted wing drosophila was found in California in 2008 infesting strawberries and caneberries (Bolda et al. 2009; Lehnert 2010; Walsh et al. 2011). In 2009 it spread up the Pacific Coast to infest fruit in Oregon, Washington, and the Fraser Valley of British Columbia. The spotted wing drosophila is now found in all western counties of Washington State, and in eight eastern counties. In 2009, it was found in Florida (Anonymous 2009b; Acheampong 2010; Lehnert 2010), where it was found in feeding lure traps $4.8 \mathrm{~km}$ apart. In 2010 it was found in Louisiana, South Carolina, North Carolina (H. J. Burrack, unpubl. data) and Michigan (Milkovich 2010; Isaacs 2011). In 2011, SWD was detected in Georgia, Virginia, Alabama (H. J. Burrack, unpubl. data; D. G. Pfeiffer, unpubl. data), New Jersey (Rodriguez-Saona and Polk 2011), and Pennsylvania (Anonymous 2011). 
Fig. 19.4 Comparison of ovipositor of spotted wing drosophila with another Drosophila sp. (Photo by Hannah Burrack)

\subsubsection{Appearance}

Females have a relatively large serrated ovipositor (Fig. 19.4), unusual among the drosophilids. The typically modest development of female terminalia in Drosophila spp. was described by Demerec (1965). Males have a single spot present on the first 
Fig. 19.5 Comparison of wing of male spotted wing drosophila with female (Photo by Hannah Burrack)



vein at the distal end of each wing (Fig. 19.5) and a unique sex comb arrangement on the basitarsis and first tarsomere of their forelegs. Larvae reach a length of $3.5 \mathrm{~mm}$ (Walsh et al. 2011).

\subsubsection{Biology}

The spotted wing drosophila has been often reported to attack grapes (Anonymous 2009a; Dreves et al. 2009; Anonymous 2010). Other hosts include apples, figs, hardy kiwi, apricots, persimmons, pluots, blackberries, blueberries, cherries, nectarines, peaches, pears, plums, raspberries, strawberries, their wild relatives, and at least one native weed, Phytolacca americana L. (Anonymous 1993; Bolda et al. 2009; Acheampong 2010; Walsh et al. 2011). Reports from Japan indicate that grape is among the most vulnerable fruit crops (Anonymous 2009b, 2010; Walsh et al. 2010), and that grape is a preferred late season host (Walsh et al. 2010). Additional work is needed to determine the crops at greatest risk in North America.

There are important gaps in our knowledge of the basic biology of this pest (Bolda et al. 2009). The spotted wing drosophila prefers warm areas, but tolerates the cold of northern Japan (Bolda et al. 2009). The range of drosophilids is limited by cold tolerance. In an effort to predict the ability of selected drosophilid species to expand their geographic ranges, Kimura (2004) measured the $\mathrm{LT}_{25}, \mathrm{LT}_{50}$, and $\mathrm{LT}_{75}$ 


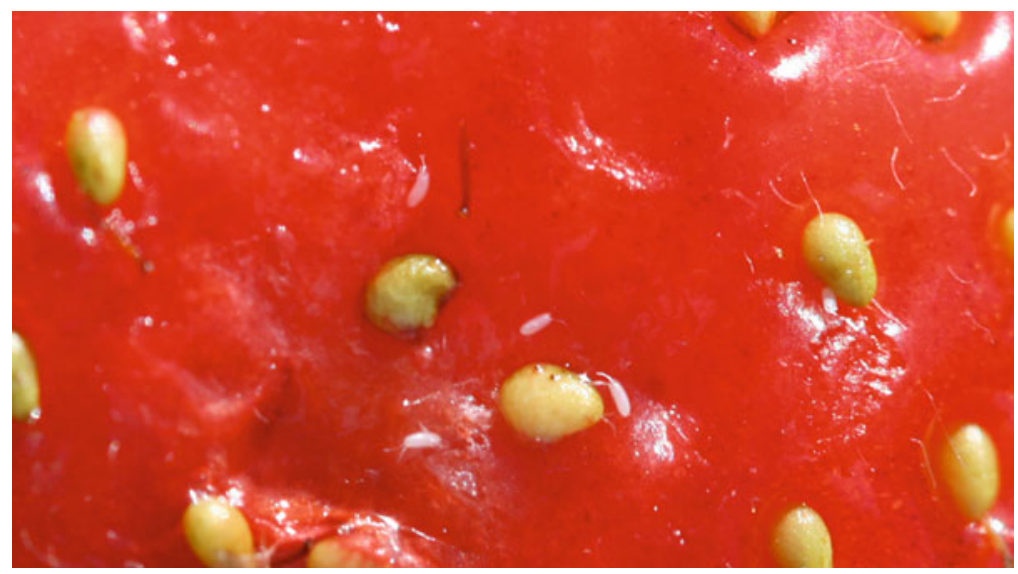

Fig. 19.6 Eggs of spotted wing drosophila in a strawberry (Photo by Hannah Burrack)

(Lethal Temperature) of northern and southern strains of several species. There was little difference in northern and southern representative strains of SWD. However, this study used non-adapted, non-diapausing individuals for testing, and their conclusions may be conservative. Although a congeneric species, D. lutescens Okada, cannot tolerate winter conditions in Sapporo, Japan, it is common in this region in summer and autumn (Kimura 2004). This period is the most problematic for SWD management in vineyards. All life stages may die when frozen. However, adults are more tolerant to cold temperatures and may survive short periods of freezing or sustained cool temperatures $\left(10^{\circ} \mathrm{C}\right)$ for longer periods (Dalton et al. 2011).

In Japan, there are up to 13 generations. A life cycle can be completed in 8-14 days, but adults can live up to 9 weeks. Females use the atypically large and serrated ovipositor to lay eggs in fruits before they become overripe and soft. Eggs are inserted under the skin of ripe or ripening fruit. Each female lays 7-16 eggs per day. Eggs have prominent respiratory horns projecting from one end (Fig. 19.6). Eggs hatch in 1-3 days, and larval feeding on the flesh causes a collapse of localized tissue after another 2 days, followed by growth of fungal or bacterial organisms; yeasts may be carried on the ovipositor (Walsh et al. 2010). Larvae are slender white maggots (Fig. 19.7). Pupae are brown and seed-like, about $3 \mathrm{~mm}$ long, with two small respiratory horns protruding from one end.

\subsubsection{Injury}

Cherries were reported to have 70-80\% injury by SWD, with eggs laid in sound fruit, by Kamizawa (1936) (cited by Demerec 1965). Growers of blueberries, caneberries and cherries, were reported to have experienced injury levels ranging 


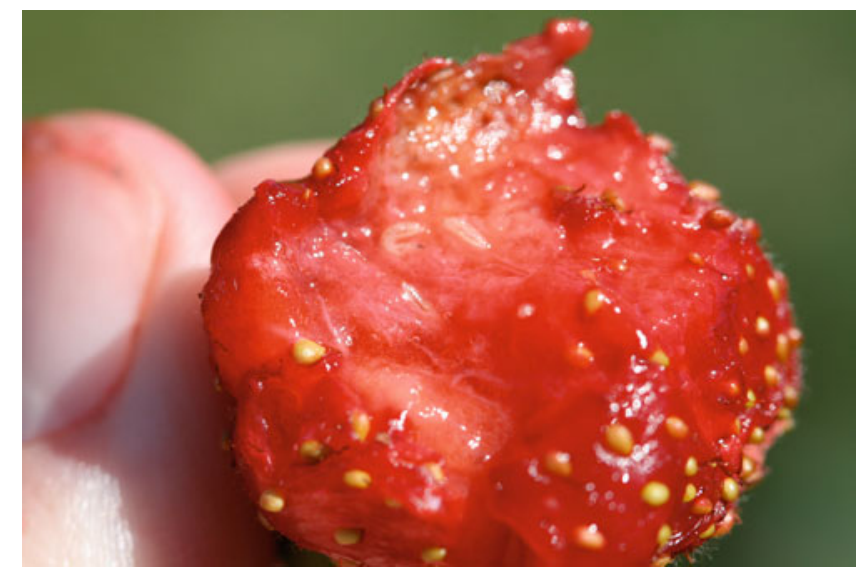

Fig. 19.7 Larvae of spotted wing drosophila in a strawberry (Photo by Hannah Burrack)

from $33 \%$ to $100 \%$ (Lehnert 2010). The economic significance of SWD in wine grapes remains unclear. However, in Japan seasonal activity was found to be greatest when cherries and grapes were ripening; this occurs in the fifth and sixth generation of the 10 seasonal generations observed in the Far East (Kanzawa 1939; Walsh et al. 2011). Walsh (2011) reported that while blueberry, blackberry, raspberry, marionberry, boysenberry, strawberry, cherry and peach are considered being of prime importance, grapes are also considered at risk.

\subsubsection{Management}

\subsubsection{Monitoring}

Traps baited with either yeast or apple cider vinegar may be used for monitoring adults (Fig. 19.8). Instructions for construction of simple plastic cup traps are presented by Walsh et al. (2010). Traps should be checked at least weekly. Most of the Drosophila flies collected will not be SWD, so the flies collected must be filtered from the trap fluid and poured into a white pan. Male SWD have a characteristic black spot at the tip of the wings. Females lack this spot, but are slightly larger than females of other fruit fly species, and have a larger ovipositor.

Caprile et al. (2010) mentioned the use of traps to protect cherries in home gardens. This would likely be impractical for large plantings such as commercial vineyards. Use of such traps early in the season may give early warning of the presence of SWD. There seems to be little relationship between trap captures and the degree of fruit damage. Traps are best used to determine presence and not density. 
Fig. 19.8 Trap for spotted wing drosophila baited with apple cider vinegar (Photo by Hannah Burrack)

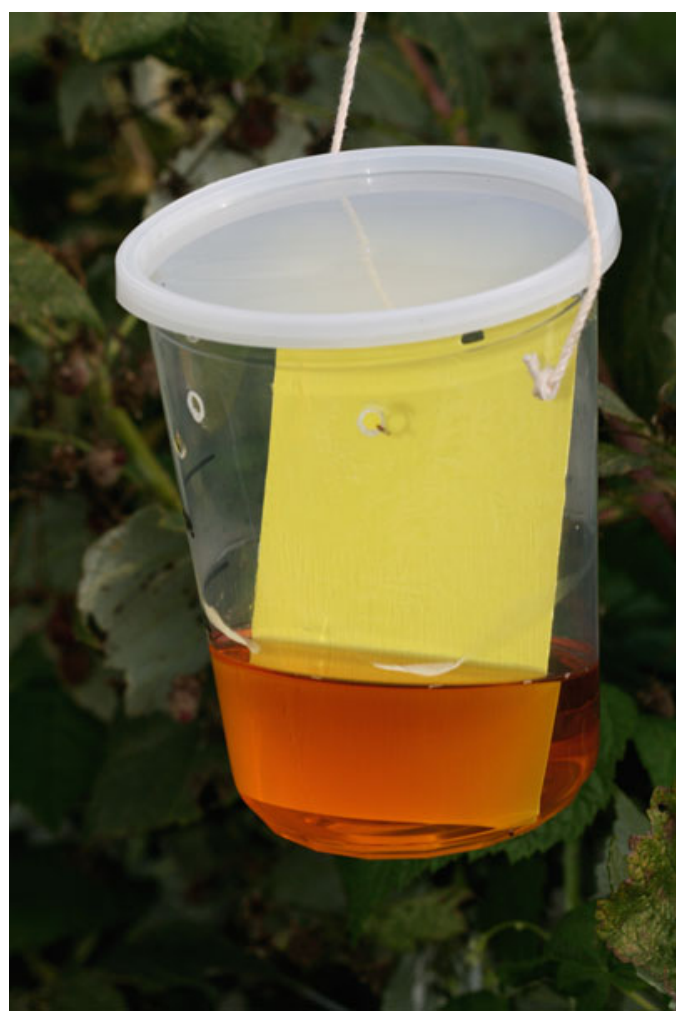

\subsubsection{Chemical Control}

Control measures are directed against the adults. There are no effective controls for larvae in the fruit. Insecticides with different modes of action should be rotated in order to delay the development of pesticide resistance. Walsh et al. (2010) recommended the following insecticides: malathion, spinosad, spinetoram, acetamiprid, imidacloprid, and thiamethoxam. In addition, fenpropathrin and zeta-cypermethrin may be effective. However, these last two products may disrupt biological control components of vineyard pests.

\subsubsection{Cultural and Physical Control}

Fruit must be harvested promptly to eliminate breeding sites. This issue should be kept in mind once SWD has established in an area, because grape growers may occasionally leave berries on the vines to allow greater development of some harvest parameters. Any overripe or rotten fruits nearby should be destroyed. If a crop is found to be infested with SWD, especially if not known to be established in the 
area, it should be destroyed after samples are taken for proper identification. Solarization and burying are being explored as means of destruction of infested fruit. Destruction of infested fruit will be especially important when there are nearby blocks approaching maturity (Walsh et al. 2011). As fruit approach maturity, covering plants with netting may be helpful (Walsh et al. 2011), but this may be difficult in a vineyard setting.

\subsection{Multicolored Asian Lady Beetle}

\subsubsection{Introduction}

The multicolored Asian lady beetle (MALB), Harmonia axyridis (Pallas), is an exotic coccinellid, and is now common in many North American and European cropping systems. It has come to dominate the coccinellid fauna (LaMana and Miller 1996; Brown and Miller 1998; Harmon et al. 2007; Lucas et al. 2007; Mizell 2007; Finlayson et al. 2008). Snyder and Evans (2006) discussed several possible ecological factors potentially involved in promoting high numbers of introduced arthropod predators, including absence of natural enemies, competition, intraguild predation, and disease transmission.

Koch (2003) reported its native range from the Altai Mountains (Siberia) to the Pacific Ocean, and southern Siberia to southern China. Many attempts to introduce MALB into North America have taken place since 1916, though it apparently did not establish until 1988 (Koch 2003). It has since spread to South America and Europe (Koch et al. 2006). The multicolored Asian lady beetle is now an important contributor to biological control. It is an important factor in reducing the soybean aphid, Aphis glycines Matsumura, another invasive species (Landis et al. 2004). Compounds have been evaluated for repellency to MALB (Riddick and Aldrich 2004). Camphor repelled adults but its effectiveness was too short lived. DEET was also repellent but studies on urban structures are needed. There is some potential for modifying behavior with plant products. Menthol, catnip and grapefruit seeds have been reported to cause avoidance by MALB (Riddick et al. 2000, 2008).

\subsubsection{Appearance}

The multicolored Asian lady beetle (Fig. 19.9) is described by several authors (Obata 1997; Nalepa et al. 2004; Pfeiffer 2008). There is a large amount of variation in color, giving rise to the common name. The background color ranges from light orange or pink to dark red, with 19 spots ranging from unapparent to heavy black patches (color forms termed succinea 1 and 2 by Seo et al. (2008)). More rarely the beetle is black with red spots (color forms conspicua and spectabilis). This color 




Fig. 19.9 Adult multicolored Asian lady beetle

variation is affected by genetics, larval diet, and seasonal effects (Koch 2003). It is also partly affected by nonrandom mating (Seo et al. 2008). The pronotum is white with a black M- or W-shaped pattern, sometimes reduced to a pair of curved lines. Larvae are dark gray to black with orange patches, with two- or three-pronged scoli. The scoli are projections from the dorsal abdominal surface and they are branched, unlike those of other coccinellids. There are four instars, which can be distinguished by coloration: first instar - dark blackish coloration; second instar - same as first instar but with orange on the dorsolateral areas of first and/or second abdominal segment; third instar - orange color extends to dorsolateral areas of second through fifth abdominal segments; fourth instar - same coloration as third, but the scoli on fourth and fifth abdominal segments are also orange (Koch 2003).

\subsubsection{Biology}

LaMana and Miller (1998) determined temperature-dependent developmental rates, with $267.3 \mathrm{DD}>11.2^{\circ} \mathrm{C}$ required for the development from egg to adult. At $26^{\circ} \mathrm{C}$, 2.8 days were spent in the egg state, and 2.5, 1.5, 1.8, and 4.4 days in the four larval instars. The pupal stage was 4.5 days. Adults may live up to 3 years (Koch 2003). Females can lay an average of 1,642 eggs (Stathas et al. 2001), in batches of 20-30 (Takahashi 1987). However, when food is a limiting factor, larvae grow more slowly, producing smaller and less fecund adults (Agarwala et al. 2008). Nutritional 
requirements for development of MALB were studied by Agarwala et al. (2008). To some extent, MALB can compensate for low prey availability by feeding at extrafloral nectaries and the presence of such nectaries may interfere with biological control (Spellman et al. 2006). Presence of aphids enhances mate-finding behavior of MALB males, and receptivity to mating by females (Obata 1997).

The multicolored Asian lady beetle is bivoltine in much of its range, including North America (Koch 2003), though up to five generations have been reported (Katsoyannos et al. 1997). Adults search for overwintering sites in late October, seeking out isolated shapes on the horizon (Obata 1986). As winter approaches, their supercooling point drops to $-16^{\circ} \mathrm{C}$ to $-19^{\circ} \mathrm{C}$ (Watanabe 2002), and in Minnesota, even to $-24^{\circ} \mathrm{C}$ (Carillo et al. 2004). Mating often occurs as adults leave overwintering sites (LaMana and Miller 1996), though $12-41 \%$ of females had sperm in their spermathecae in collections at North Carolina overwintering sites (Nalepa et al. 1996). Parts of its North American range exhibit winter temperatures that should be lethal. The beetle finds suitable microclimates in the fall, making winter minimum temperatures a poor indicator of potential range (Carillo et al. 2004; Labrie et al. 2008).

Intraguild predation has been raised as a factor related to the high numbers of MALB, and affecting the efficacy of other predators. Burgio et al. (2002) reported that in feeding trials with the native coccinellid, Adalia bipunctata (L.), intraguild predation between the two coccinellids was generally less than within-species egg cannibalism by A. bipunctata. In a biological control study for the hemlock woolly adelgid, Adelges tsugae Annand, two specialists Laricobius nigrinus Fender and Sasajiscymnus (=Pseudoscymnus) tsugae Sasaji \& McClure, were examined with MALB. All species fed on eggs of the two specialists, but eggs of MALB were only fed upon by MALB, putting it at an advantage (Flowers et al. 2005). Cannibalism by siblings is a trait of MALB. Osawa (1993) concluded that sibling cannibalism was density-independent and the non-sibling cannibalism was density-dependent. A different situation exists with larval intraguild predation. When exposed to foraging MALB, larval Coccinella septempunctata L. were more likely than A. bipunctata to drop from the plant. As a result, $95 \%$ of A. bipunctata larvae were consumed by MALB, compared with about 54\% of C. septempunctata larvae (Sato et al. 2005). Intraguild egg predation by MALB and lack of feeding on MALB eggs by other coccinellid species may have favored the spread and population increase of MALB in Great Britain (Snyder et al. 2000; Ware et al. 2008).

\subsubsection{Injury}

Adult MALB have been reported feeding on the fruit of peaches, apples, raspberries and grapes (Kovach 2004). In order to determine whether beetle presence represented a primary or secondary problem, fruit of several types were placed in screened containers: 'Gala' apples, 'Redhaven' peaches, and 'Red Flame' seedless grapes. Some fruit were injured mechanically to simulate bird-injured fruit while other fruit were left uninjured as controls. Beetles were much more likely to feed on injured 
than on uninjured fruit. However, uninjured fruit, mainly grapes, were also fed on by adult MALB. Moreover, injured grapes were also twice as attractive as injured apples or peaches. However, that study involved caged beetles and fruit, and only a minority of beetles fed upon grape berries. In contrast, Koch et al. (2004) reported that MALB do not cause primary feeding injury to grapes. Galvan et al. (2006a) found that MALB were more likely to be found in clusters if berries had been previously injured, and that simple presence of MALB was not a problem unless accompanied by injured fruit. It appears that, while MALB is capable of feeding on uninjured grape berries, beetles fed preferentially on previously injured fruit. Hence, vineyard managers should be most mindful of MALB in blocks where fruit exhibit splitting from rain, birds or insect injury after berries have started to accumulate sugars.

Galvan et al. (2009) found that there was a major peak of MALB flight activity between veraison and harvest, allowing greater numbers in vineyards at the most vulnerable time. Populations in vineyard surroundings peak about 10 days earlier than populations in vineyards.

\subsubsection{Effect on Wine}

Tasting panels in Ohio noted an occasional taste reminiscent of 'rancid peanut or cooked spinach odor.' This could mask varietal characteristics of wine, and judges reported that the odor was similar to MALB found in homes in the area (Kovach 2004). In a preliminary assessment of effects of beetles crushed with the berries on wine quality, Kovach (2004) crushed 100 MALB adults in $100 \mathrm{ml}$ of white wine, centrifuged and filtered, and this product was used to spike various concentrations of wine. The detection limit was determined to be about 1.2 beetles per liter, about one per bottle. A field threshold was set of 12 beetles per lug. Fermenting MALB with the wine causes altered aroma and flavor profiles (Pickering et al. 2004). Pickering et al. (2005) found that 2-Isopropyl-3-methoxypyrazine (IPMP) was determined to be above a sensory threshold when fermented with MALB. The aroma and flavor profiles of aged wines were not different from fresh wines, with reduced fruit and floral traits in red and white wines. Research on potential remedial treatments for wine have shown that IPMP titers were lowered by activated charcoal in white wine, deodorized oak in red wine, and the addition of oak chips reduced the 'ladybug taint' in both red and white wines (Pickering et al. 2006).

\subsubsection{Domestic Invasion}

Huelsman et al. (2002) reported that the movement of adults to overwintering sites starts on the first day when temperatures exceed $18^{\circ} \mathrm{C}$ after near-freezing temperatures have been reached. Adult MALB sometimes enter buildings in large numbers, creating a nuisance. There may be a greater risk of allergic responses because of its greater proximity to humans (Yarbrough et al. 1999). Beetles prefer buildings with at least one wooded side. Caulking of cracks and other spaces is helpful but not sufficient (Huelsman and Kovach 2004). Beetles are kept out by $2 \mathrm{~mm}$ gaps, though most 
can pass through a $3 \mathrm{~mm}$ gap (Nalepa 2007). Beetles prefer to land on structures with high contrast patterns of light and dark. Unfortunately, many structures on buildings (drain pipes, gutters, etc.) cast contrasting shadows that may be attractive to immigrating MALB adults (Nalepa et al. 2004, 2005).

\subsubsection{Management}

\subsubsection{Monitoring}

Galvan et al. (2007) examined the distribution of MALB in vineyards, and developed sequential sampling programs. The distribution was determined to be random at low densities, and aggregated at higher densities. Enumerative and binomial sampling plans were compared. For management purposes, an average sample of 180 clusters were needed to determine the population at precision level of $0.25(\mathrm{SE} / \bar{x})$. However, binomial sampling plans were more efficient for pest management purposes, where 19-26 clusters were needed to determine the action threshold of one beetle per cluster. Correct decisions were made in $83-96 \%$ of the time. Sampling should be initiated 2-3 weeks before harvest. In the final week, sampling should precede the PHI of the insecticide to be employed.

\subsubsection{Chemical Control}

Buprofezin is highly toxic to MALB larvae, but showed only low-moderate toxicity to MALB pupae (James 2004). In a vineyard comparison, bifenthrin, carbaryl, zetacypermethrin, imidacloprid and thiamethoxam reduced adult populations in clusters (Galvan et al. 2006b). In the laboratory, residues of bifenthrin, carbaryl, and thiamethoxam were all toxic to MALB 7 days following treatment. In 2006, few insecticides registered on grape had sufficiently short PHIs to allow their use to control MALB. The choice was limited to carbaryl, malathion, and imidacloprid. Indoxacarb was toxic to third instars and adults while spinosad was ineffective (Galvan et al. 2006c). Vineyard managers should check current labels for effective materials registered with the required short PHI. For example, clothianidin now has MALB on the label, with a 0-day PHI (Valent U.S.A Corporation 2010) and dinotefuran has a 1-day PHI (Cornell Cooperative Extension Publication 2010).

\subsubsection{Biological Control}

Koch (2003) reviewed the biological control literature of MALB, listing several parasitoids. The phorid Phalacrotophora philaxyridis Disney has been reported in Asia, but may have also followed MALB to North America. Two tachinids attack MALB adults: Degeria lutuosa Meingen in Korea (Park et al. 1996) and Strongygaster triangulifera (Loew) in North America. The braconid Dinocampus (=Perilitus) 
coccinellae (Schrank) parasitized MALB in Korea and North America. A parasitic fungus specific to Coccinellidae was found infecting MALB in Pennsylvania, with infection levels $>50 \%$ (Riddick and Schaefer 2005). Nalepa et al. (1996) reported overwintering adults to be parasitized by the tachinid $S$. triangulifera at levels of $14.2 \%$ and $1.4 \%$, respectively in 1993 and 1994. Spiroplasma bacteria kill only male embryos, potentially resulting in a skewed sex ratio (Nakamura et al. 2005).

\subsubsection{Mechanical Control}

Floating row covers successfully reduced the number of adults per cluster (Galvan et al. 2006b).

\subsection{Prospects}

It is likely that both BMSB and SWD will continue to expand their geographic ranges. Their presence will present a complication for vineyard management at harvest. However, the magnitude of this disruption is still unclear. Bolda et al. (2009) projected significant losses to Pacific Coast small fruit crops from SWD, particularly if trade barriers are erected. There will likely be greater pesticide use shortly before harvest of grapes and other fruits and vegetables. Pesticide efficacy trials are now underway in many locations and optimum choices for chemical control would be available in the near future. Currently there is cause for concern, because the pyrethroid class, providing some of the greatest mortality at this time, has extremely negative effects on vineyard IPM programs, potentially inducing secondary pest problems. Some of these pests (e.g., mealybugs, Chap. 12) are vectors of important grapevine diseases. Under a global warming scenario, it is likely that BMSB will become a greater problem, because of decreased winter mortality. Based on a Japanese study, each increase of $1{ }^{\circ} \mathrm{C}$ is expected to result in approximately $13.5-16.5 \%$ decrease of winter mortality (Musolin 2007). In addition, earlier spring emergence of BMSB has been seen because of higher early spring temperatures. The wide host range of BMSB and SWD will complicate control programs (Nielsen and Hamilton 2009a). Efforts may be needed at the landscape level. MALB has been present in vineyards for a longer period of time. It now seems that this insect will pose the greatest threat not from primary injury to berries, but by concentrating in clusters that are already injured by other organisms. Hence, managers should be vigilant in order to protect wine quality.

\section{References}

Acheampong S (2010) Spotted wing drosophila (Drosophila suzukii), a new vinegar fly pest in British Columbia. British Columbia Ministry of Agriculture and Lands, Kelowna, BC Agarwala BK, Yasuda H, Sato S (2008) Life history response of a predatory ladybird, Harmonia axyridis (Pallas) (Coleoptera: Coccinellidae), to food stress. Appl Entomol Zool 43:183-189 
Aldrich JR (1988) Chemical ecology of the Heteroptera. Annu Rev Entomol 33:211-238

Aldrich JR, Khrimian A, Camp MJ (2007) Methyl 2,4,6-decatrienoates attract stink bugs and tachinid parasitoids. J Chem Ecol 33:801-815

Aldrich JR, Khrimian A, Chen X, Camp MJ (2009) Semiochemically based monitoring of the invasion of the brown marmorated stink bug and unexpected attraction of the native green stink bug (Heteroptera: Pentatomidae) in Maryland. Fla Entomol 92:483-491

Anonymous (1993) Host plants of Drosophila suzukii. Pest Res Rep 44. www.affrc.go.jp/ja/ research/seika/data_tnaes/h05/tnaes93122

Anonymous (2009a) Fruit fly pest identified in wine grapes. Science Daily. Oregon State University, Corvallis. http://www.sciencedaily.com/releases/2009/10/091015163605.htm

Anonymous (2009b) Spotted wing drosophila, Drosophila suzukii (Matsumura) (Diptera: Drosophilidae), a Fruit Pest New to North America and Florida. University of Florida, Gainesville, FL

Anonymous (2010) Pest alert: spotted wing drosophila. Oregon Department of Agriculture, Corvallis. http://www.oregon.gov/ODA/PLANT/IPPM

Anonymous (2011) New fruit pest found in Pennsylvania. Pennsylvania Integrated Pest Management, http://extension.psu.edu/ipm/news/2011/new-fruit-pest-found-in-pennsylvania

Bolda MP, Goodhue RE, Zalom FG (2009) Spotted wing drosophila: potential economic impact of a newly established pest. Giannini Foundation of Agricultural Economics, University of California, Berkeley, CA

Brown MS, Miller SS (1998) Coccinellidae (Coleoptera) in apple orchards of eastern West Virginia and the impact of invasion by Harmonia axyridis. Entomol News 109:143-151

Burgio F, Santi F, Maini S (2002) On intra-guild predation and cannibalism in Harmonia axyridis (Pallas) and Adalia bipunctata L. Biol Control 24:110-116

Caprile JM, Flint L, Bolda MP, Coates WW, Grant JA, Zalom FG, Van Steenwyck RA, Haviland D (2010) Spotted wing drosophila, Drosophila suzukii: a new pest in California. http://www. ipm.ucdavis.edu/EXOTIC/drosophila.html

Carillo MA, Koch RL, Venette RC, Cannon CA, Hutchison WD (2004) Response of the multicolored Asian lady beetle (Coleoptera: Coccinellidae) to low temperatures: implications for winter survival. Am Entomol 50:157-158

CDFA (2005) New state records: Halyomorpha halys (Stål) (Pentatomidae), California plant pest and disease report. California Department of Food and Agriculture, Sacramento

Cornell Cooperative Extension Publication (2010) 5.3 pest management guidelines. Pest management schedules for minor insects. Cornell University and PennState, NY and PA. http:// ipmguidelines.org/Grapes/content/CH05/default-3.asp

Dalton DT, Walton VM, Shearer PW, Walsh DB, Caprile J, Isaacs R (2011) Laboratory survival of Drosophila suzukii under simulated winter conditions of the Pacific Northwest and seasonal field trapping in five primary regions of small and stone fruit production in the United States. Pest Manag Sci 67:1368-1374

Day ER, McCoy T, Miller D, Kuhar TP, Pfeiffer DG (2011) Brown marmorated stink bug, Hemiptera, Pentatomidae: Halyomorpha halys. Virginia Tech, Fact Sheets 2902-1100:1-2

Demerec M (1965) Biology of drosophila. Hafner, New York, NY

Dreves AJ, Fisher G, Walton V (2009) A new pest attacking healthy ripening fruit in Oregon: spotted wing drosophila, Drosophila suzukii (Matsumura), regional pest alert. Oregon State University, Corvallis

EOL (2011) Halyomorpha halys: brown marmorated stink bug. Encyclopedia of life. http://eol. org/pages/3686128/overview

Finlayson CJ, Landry KM, Alyokhin AV (2008) Abundance of native and non-native lady beetles (Coleoptera: Coccinellidae) in different habitats in Maine. Ann Entomol Soc Am 101: 1078-1087

Flowers RW, Salom SM, Kok LT (2005) Competitive interactions among two specialist predators and a generalist predator of hemlock woolly adelgid, Adelges tsugae (Homoptera: Adelgidae), in the laboratory. Environ Entomol 34:664-675

Funayama K (2006) A new rearing method using carrots as food for the brown marmorated stink bug, Halyomorpha halys (Stål) (Heteroptera: Pentatomidae). Appl Entomol Zool 41:415-418 
Funayama K (2007) Reproduction of the brown marmorated stink bug, Halyomorpha halys (Stål) (Heteroptera: Pentatomidae) on Japanese bird cherry trees, Prunus grayana Maxim. Jpn J Appl Entomol Zool 51:238-240

Galvan TL, Burkness EC, Hutchison WD (2006a) Influence of berry injury on infestations of the multicolored Asian lady beetle in wine grapes. Plant Health Prog doi:10.1094/PHP-20060607-01-BR

Galvan TL, Burkness EC, Hutchison WD (2006b) Efficacy of selected insecticides for management of the multicolored Asian lady beetle on wine grapes near harvest. Plant Health Prog doi:10.1094/PHP-2006-1003-01-RS

Galvan TL, Koch RL, Hutchison WD (2006c) Toxicity of indoxacarb and spinosad to the multicolored Asian lady beetle, Harmonia axyridis (Coleoptera: Coccinellidae), via three routes of exposure. Pest Manag Sci 62:797-804

Galvan TL, Burkness EC, Hutchison WD (2007) Enumerative and binomial sequential sampling plans for the multicolored Asian lady beetle (Coleoptera: Coccinellidae) in wine grapes. J Econ Entomol 100:1000-1010

Galvan TL, Burkness EC, Koch RL, Hutchison WD (2009) Multicolored Asian lady beetle (Coleoptera: Coccinellidae) activity and wine grape phenology: implications for pest management. Environ Entomol 38:1563-1574

Gyeltshen J, Bernon G, Hodges A (2010). Brown marmorated stink bug, Halyomorpha halys Stål (Insecta: Hemiptera: Pentatomidae). University of Florida IFAS Extension. http://edis.ifas.ufl. edu/in623

Halbert SE (2009) Tri-ology. Entomology section, DACS-P-00124. Florida Department of Agriculture and Consumer Services

Hamilton GC, Shearer PW, Nielsen AL (2008) Brown marmorated stink bug: a new exotic insect in New Jersey. R. U. C. Extension, New Brunswick, NJ

Harmon JP, Stephens E, Losey J (2007) The decline of native coccinellids (Coleoptera: Coccinellidae) in the United States and Canada. J Insect Conserv 11:85-94

Henderson W, Khalilian A, Han Y (2006) Detecting stink bugs/damage in cotton utilizing a portable electronic nose, paper number 061103. In: ASABE annual international meeting, 9-12 July 2006, Portland, OR, pp 1-10

Hoebeke ER (2002) Brown marmorated stink bug, Halyomorpha halys (Stål): Heteroptera: Pentatomidae. Entomol Circ 204:34-38

Hoebeke ER, Carter ME (2003) Halyomorpha halys (Stål) (Heteroptera: Pentatomidae): a polyphagous plant pest from Asia newly detected in North America. Proc Entomol Soc Wash 105:225-237

Hoffmann WE (1931) A pentatomid pest of growing beans in south China. Peking Nat Hist Bull $5: 25-26$

Huelsman MF, Kovach J, Jasinski J, Young C, Eisley B (2002) Multicolored Asian lady beetle (Harmonia axyridis) as a nuisance pest in households in Ohio. In: Jones SC, Zhai J, Robinson WH (eds) Proceedings of the 4th international conference on urban pests, 7-10 July 2002, Charleston, USA, pp 243-250

Huelsman M, Kovach J (2004) Behavior and treatment of the multicolored Asian lady beetle (Harmonia axyridis) in the urban environment. Am Entomol 50:163-164

Isaacs R (2011) First detection and response to the arrival of spotted wing drosophila in Michigan. Newsl Michigan Entomol Soc 56:10-12

James DG (2004) Effect of buprofezin on survival of immature stages of Harmonia axyridis, Stethorus punctum picipes (Coleoptera: Coccinellidae), Orius tristicolor (Hemiptera: Anthocoridae), and Geocoris spp. (Hemiptera: Geocoridae). J Econ Entomol 97:900-904

Jones JR, Lambdin PL (2009) New county and state records for Tennessee of an exotic pest, Halyomorpha halys (Hemiptera: Pentatomidae), with potential economic and ecological implications. Fla Entomol 92:177-178

Kamizawa T (1936) Studies on Drosophila suzukii Mats. J Plant Prot 23(66-70):127-132

Kanzawa T (1939) Studies on Drosophila suzukii Mats. Rev Appl Entomol 29:622 
Katsoyannos P, Kontodimas DC, Stathas GJ, Tsartsalis CT (1997) Establishment of Harmonia axyridis on citrus and some data on its phenology in Greece. Phytoparasitica 25:183-191

Kawada H, Kitamura C (1983) The reproductive behavior of the brown marmorated stink bug, Halyomorpha mista Uhler (Heteroptera: Pentatomidae). I. Observation of mating behavior and multiple copulation. Appl Entomol Zool 18:234-242

Kawada H, Kitamura C (1992) The tachinid fly, Bogosia sp. (Diptera: Tachinidae) as a parasitoid of the brown marmorated stink bug, Halyomorpha mista Uhler (Heteroptera: Pentatomidae). Jpn J Environ Entomol Zool 4:65-70

Kelly T (2010) A stinky situation, Grape Press (Virginia Vineyards Association) 26(3):1, 7-8

Khrimian A, Shearer PW, Zhang A, Hamilton GC, Aldrich JR (2008) Field trapping of the invasive brown marmorated stink bug, Halyomorpha halys, with geometric isomers of methyl 2,4,6-decatrienoate. J Agric Food Chem 56:197-203

Kimura MT (2004) Cold and heat tolerance of drosophilid flies with reference to their latitudinal distributions. Oecologia 140:442-449

Kiritani K (2006) Predicting impacts of global warming on population dynamics and distribution of arthropods in Japan. Popul Ecol 48:5-12

Kiritani K (2007) The impact of global warming and land-use change on the pest status of rice and fruit bugs (Heteroptera) in Japan. Glob Change Biol 13:1586-1595

Koch RL (2003) The multicolored Asian lady beetle, Harmonia axyridis: a review of its biology, uses in biological control, and non-target impacts. J Insect Sci 3:1-16

Koch RL, Burkness EC, Wold-Burkness SJ, Hutchison WD (2004) Phytophagous preferences of the multicolored Asian lady beetle (Coleoptera: Coccinellidae) to autumn ripening fruit. J Econ Entomol 97:539-544

Koch RL, Venette RC, Hutchison WD (2006) Invasions by Harmonia axyridis (Pallas) (Coleoptera: Coccinellidae) in the Western Hemisphere: implications for South America. Neotrop Entomol 35:421-434

Koppel AL (2010) Stink bug egg studies in southeastern Virginia: parasitoid survey, and susceptibility and chorion permeability to insecticides. Ph.D. dissertation, Virginia Polytechnic Institute and State University, Blacksburg, VA

Kovach J (2004) Impact of multicolored Asian lady beetles as a pest of fruit and people. Am Entomol 50:159-161

Labrie G, Coderre D, Lucas É (2008) Overwintering strategy of multicolored Asian lady beetle (Coleoptera: Coccinellidae): cold-free space as a factor of invasive success. Ann Entomol Soc Am 101:860-866

LaMana ML, Miller JC (1996) Field observations on Harmonia axyridis Pallas (Coleoptera, Coccinellidae) in Oregon. Biol Control 6:232-237

LaMana ML, Miller JC (1998) Temperature-dependent development in an Oregon population of Harmonia axyridis (Coleoptera: Coccinellidae). Environ Entomol 27:1001-1005

Landis DA, Fox TB, Costamagna AC (2004) Impact of multicolored Asian lady beetle as a biological control agent. Am Entomol 50:153-155

Lehnert D (2010) New fruit fly is more than just a nuisance. Fruit Growers News 49:12

Leskey T (2011) The challenges posed by the invasive brown marmorated stink bug, Halyomorpha halys (Stål), to U.S. agriculture. U. S. Department of Agriculture-ARS, Kearneysville

Lucas E, Vincent C, Labrie G, Chouinard G, Fournier F, Pelletier F, Bostanian NJ et al (2007) The multicolored Asian ladybeetle Harmonia axyridis (Coleoptera: Coccinellidae) in Quebec agroecosystems ten years after its arrival. Eur J Entomol 104:737-744

Maine Department of Agriculture (2006) Interception of the brown marmorated stink bug (Halyomorpha halys) in Maine. Maine Department of Agriculture, Division of Plant Industry. http://www.maine.gov/agriculture/pi/pestsurvey/pestinfo/BMSB.htm

Markow TA, O'Grady PM (2006) Drosophila: a guide to species identification and use. Academic, London

Milkovich M (2010) SWD found in Michigan; team planning a response. Fruit Growers News November, pp 1-14 
Mizell RF (2007) Impact of Harmonia axyridis (Coleoptera: Coccinellidae) on native arthropod predators in pecan and crape myrtle. Fla Entomol 90:524-536

Musolin DL (2007) Insects in a warmer world: ecological, physiological and life-history responses of true bugs (Heteroptera) to climate change. Global Change Biol 13:1565-1585

Nakamura K, Ueno H, Miura K (2005) Prevalence of inherited male-killing microorganisms in Japanese population of ladybird beetle Harmonia axyridis (Coleoptera: Coccinellidae). Ann Entomol Soc Am 98:96-99

Nakashima N, Sasaki J, Tsuda K, Yasunaga C, Noda H (1998) Properties of a new picorna-like virus of the brown-winged green bug, Plautia stali. J Invertebr Pathol 71:151-158

Nalepa CA (2007) Harmonia axyridis (Coleoptera: Coccinellidae) in buildings: relationship between body height and crevice size allowing entry. J Econ Entomol 100:1633-1636

Nalepa CA, Kidd KA, Ahlstrom KR (1996) Biology of Harmonia axyridis (Coleoptera: Coccinellidae) in winter aggregations. Ann Entomol Soc Am 89:681-685

Nalepa CA, Kennedy GG, Brownie C (2004) Orientation of multicolored Asian lady beetles to buildings. Am Entomol 50:165-166

Nalepa CA, Kennedy GG, Brownie C (2005) Role of visual contrast in the alighting behavior of Harmonia axyridis (Coleoptera: Coccinellidae) at overwintering sites. Environ Entomol 34:425-431

Nielsen AL, Hamilton GC (2009a) Life history of the invasive species Halyomorpha halys (Hemiptera: Pentatomidae) in northeastern United States. Ann Entomol Soc Am 102:608-616

Nielsen AL, Hamilton GC (2009b) Seasonal occurrence and impact of Halyomorpha halys (Hemiptera: Pentatomidae) in tree fruit. J Econ Entomol 102:1133-1140

Nielsen AL, Hamilton GC, Matadha D (2008a) Developmental rate estimation and life table analysis for Halyomorpha halys (Hemiptera: Pentatomidae). Environ Entomol 37:348-355

Nielsen AL, Shearer PW, Hamilton GC (2008b) Toxicity of insecticides to Halyomorpha halys (Hemiptera: Pentatomidae) using glass-vial bioassays. J Econ Entomol 101:1439-1442

Niva CC, Takeda M (2002) Color changes in Halyomorpha brevis (Heteroptera: Pentatomidae) correlated with distribution of pteridines: regulation by environmental and physiological factors. Comp Biochem Physiol B Biochem Mol Biol 132:653-660

Obata S (1986) Determination of hibernation site in the ladybird beetle, Harmonia axyridis Pallas (Coleoptera, Coccinellidae). Kontyu 54:218-223

Obata S (1997) The influence of aphids on the behavior of adults of the ladybird beetle, Harmonia axyridis (Col.: Coccinellidae). Entomophaga 42:103-106

Osawa N (1993) Population field studies of the aphidophagous ladybird beetle Harmonia axyridis (Coleoptera: Coccinellidae): life tables and key factor analysis. Res Popul Ecol 35:335-348

Panizzi AR, McPherson JE, James DG, Javahery M, McPherson BA (2000) Stink bugs (Pentatomidae). In: Schaefer CW, Panizzi AR (eds) Heteroptera of economic importance. CRC Press, New York, pp 421-474

Park H, Park YC, Hong OK, Cho SY (1996) Parasitoids of the aphidophagous ladybeetles, Harmonia axyridis (Pallas) (Coleoptera: Coccinellidae) in Chuncheon areas, Korea. Korean J Entomol 26:143-147

Pfeiffer DG (2008) Major insect and mite pests of grape in eastern North America. In: Wolf TK (ed) Wine grape production guide for eastern North America. Natural Resource, Agriculture, and Engineering Service (NRAES), Ithaca, NY, pp. 241-261, 307-313

Pfeiffer DG, Jordan TA, Laub CA, Mays RS (2010) Elimination of brown marmorated stink bug from winegrape clusters at harvest-2010. In: Cumberland-Shenandoah fruit workers conference, 2010, Winchester, VA

Pickering GJ, Lin Y, Riesen R, Reynolds A, Brindle I, Soleas G (2004) Influence of Harmonia axyridis on the sensory properties of white and red wine. Am J Enol Vitic 55:153-159

Pickering GJ, Lin Y, Reynolds A, Soleas G, Riesen R, Brindle I (2005) The influence of Harmonia axyridis on wine composition and aging. J Food Sci 70:128-135

Pickering GJ, Lin J, Reynolds A, Soleas G, Riesen R (2006) The evaluation of remedial treatments for wine affected by Harmonia axyridis. Int J Food Sci Technol 41:77-86 
Riddick EW, Aldrich JR (2004) Search for repellents, attractants, and pheromones of the multicolored Asian lady beetle. Am Entomol 50:167-168

Riddick EW, Schaefer PW (2005) Occurrence, density, and distribution of parasitic fungus Hesperomyces virescens (Laboulbeniales: Laboulbeniaceae) on multicolored Asian lady beetle (Coleoptera: Coccinellidae). Ann Entomol Soc Am 98:615-624

Riddick EW, Aldrich JR, De Milo A, Davis JC (2000) Potential for modifying the behavior of the multicolored Asian lady beetle (Coleoptera: Coccinellidae) with plant-derived natural products. Ann Entomol Soc Am 93:1314-1321

Riddick EW, Brown AE, Chauhan KR (2008) Harmonia axyridis adults avoid catnip and grapefruit-derived terpenoids in laboratory bioassays. Bull Insectology 61:81-90

Rider DA (2005) Halyomorpha halys Stål, 1855. Pentatomoidea home page. http://www.ndsu. nodak.edu/ndsu/rider/Pentatomoidea/Species_Cappaeini/Halyomorpha_halys.htm

Rodriguez-Saona C, Polk D (2011) Spotted wing drosophila - a potential pest of New Jersey blueberries and other soft fruit. Plant Pest Advisory Rutgers Coop Ext 16(17):1-2

Sato S, Yasuda H, Evans EW (2005) Dropping behaviour of larvae of aphidophagous ladybirds and its effects on incidence of intraguild predation: interactions between the intraguild prey, Adalia bipunctata (L.) and Coccinella septempunctata (L.), and the intraguild predator, Harmonia axyridis Pallas. Ecol Entomol 30:220-224

Seo MJ, Kim GH, Youn YN (2008) Differences in biological and behavioural characteristics of Harmonia axyridis (Coleoptera: Coccinellidae) according to colour patterns of elytra. J Appl Entomol 132:239-247

Snyder WE, Evans EW (2006) Ecological effects of invasive arthropod generalist predators. Annu Rev Ecol Evol Syst 37:95-122

Snyder WE, Joseph SB, Preziosi RF, Moore AJ (2000) Nutritional benefits of cannibalism for the lady beetle Harmonia axyridis (Coleoptera: Coccinellidae) when prey quality is poor. Environ Entomol 29:1173-1179

Spellman B, Brown M, Mathews C (2006) Effect of floral and extrafloral resources on predation of Aphis spiraecola by Harmonia axyridis on apple. BioControl 51:715-724

Stathas GJ, Eliopoulos PA, Kontodimas DC, Giannopapas J (2001) Parameters of reproductive activity in females of Harmonia axyridis (Coleoptera: Coccinellidae). Eur J Entomol 98:547-549

Takahashi K (1987) Differences in oviposition initiation and sites of lady beetle, Coccinella septempunctata bruckii Mulsant and Harmonia axyridis (Pallas) (Coleoptera: Coccinellidae) in the field. Jpn J Appl Entomol Zool 31:253-254

Toyama M, Ihara F, Yaginuma K (2006) Formation of aggregations in adults of the brown marmorated stink bug Halyomorpha halys (Stål) (Heteroptera: Pentatomidae): the role of antennae in short-range locations. Appl Entomol Zool 41:309-315

Valent U.S.A Corporation (2010) Belay supplemental label. http://www.valent.com/agriculture/ products/belay/label-msds.cfm

Walsh D, O'Neal S, Brooks T (2010) Spotted wing drosophila: what Washington State wine grape growers need to know. Washington State University Extension, Pullman. swd.hort.oregonstate. edu/files/webfm/editor/Wine_Grape_SWD_Bulletin_WSU.pdf

Walsh DB, Bolda MP, Goodhue RE, Dreves AJ, Lee J, Bruck DJ, Walton VM, O'Neal SD, Zalom FG (2011) Drosophila suzukii (Diptera: Drosophilidae): invasive pest of ripening soft fruit expanding its geographic range and damage potential. J Integr Pest Manag 2:1-7

Ware RL, Yguel B, Majerus MEN (2008) Effects of larval diet on female reproductive output of the European coccinellid Adalia bipunctata and the invasive species Harmonia axyridis (Coleoptera: Coccinellidae). Eur J Entomol 105:437-444

Watanabe M (2002) Cold tolerance and myo-inositol accumulation in overwintering adults of a lady beetle, Harmonia axyridis (Coleoptera: Coccinellidae). Eur J Entomol 99:5-9

Weintraub PG, Beanland L (2006) Insect vectors of phytoplasmas. Annu Rev Entomol 51:91-111

Welty C, Shetlar D, Hammond R, Jones S, Bloetscher B, Nielsen A (2008) Brown marmorated stink bug. Ohio State University Extension Fact Sheet. http://ohioline.osu.edu/hyg-fact/pdf/ FS_3824_08.pdf 
Wermelinger B, Wyniger D, Forster B (2008) First records of an invasive bug in Europe: Halyomorpha halys Stål (Heteroptera: Pentatomidae), a new pest on woody ornamentals and fruit trees? Bull Soc Entomol Suisse 81:1-8

Yang ZQ, Yao YX, Qiu LF, Li ZX (2009) A new species of Trissolcus (Hymenoptera: Scelionidae) parasitizing eggs of Halyomorpha halys (Heteroptera: Pentatomidae) in China with comments on its biology. Ann Entomol Soc Am 102:39-47

Yarbrough JA, Armstrong JL, Blumberg MZ, Phillips AE, McGahee E, Dolen WK (1999) Allergic rhinoconjunctivitis caused by Harmonia axyridis (Asian lady beetle, Japanese lady beetle, or lady bug). J Allergy Clin Immunol 104:704-705 